\title{
Evans Syndrome following T Cell-repleted Unrelated Bone Marrow Transplantation for Myelodysplastic Syndrome: Successful Response to High-dose Corticosteroid
}

\author{
Young-Ho Lee, M.D. ${ }^{1}$, Young-Dae Kim, M.D. ${ }^{2}$ and Yeong-Myung Kim, M.D. ${ }^{3}$ \\ Department of Pediatrics, ${ }^{1}$ Hanyang University Medical Center, Seoul, ${ }^{2}$ Inje University Paik Hospital, Seoul, \\ ${ }^{3}$ Dong-A University Medical Center, Busan, Korea
}

\begin{abstract}
Evans syndrome after hematopoietic stem cell transplantation rarely occurs and this condition is refractory to treatment, particularly in childhood. We experienced a case of Evans syndrome following unmanipulated unrelated bone marrow transplantation. Evans syndrome developed at early post-transplantation period (day +42$)$ and it responded very well to high-dose corticosteroid. Autoimmune cytopenia should be considered for post-engraftment cytopenias and high-dose corticosteroid therapy might be considered as a treatment of the early onset type of autoimmune cytopenia that can occur after hematopoietic stem cell transplantation. (Korean J Hematol 2006;41:204-207.)
\end{abstract}

Key Words: Evans syndrome, $\mathrm{T}$ cell repleted bone marrow transplantation, High-dose corticosteroid

\section{INTRODUCTION}

Although autoimmune cytopenia is infrequent complication following hematopoietic stem cell transplantation (HSCT), it has been reported after allogeneic ${ }^{1-4)}$ as well as autologous stem cell transplantation. ${ }^{5,6)}$ Autoimmune cytopenia following HSCT variably responded to immunoglobulin or other immunosuppressive treatment and also associated with a high mortality rate.

Evans syndrome is direct Coombs' test positive hemolytic anemia with immune thrombocytopenic purpura, ${ }^{7-10)}$ which is rarely reported in children, particularly, who received HSCT. ${ }^{11,12)}$ We describe here an 11 years old girl with Evans

접수 : 2006년 6월 2일, 수정 : 2006년 7월 19일 승인 : 2006년 7월 24일

교신저자 : 이영호, 서울시 성동구 행당동 17번지

(9) 133-792, 한양대학교 서울병원 소아과

Tel: 02-2290-8383, Fax: 02-2297-2380

E-mail: cord@hanyang.ac.kr syndrome following unrelated bone marrow transplantation (BMT), which promptly responded to high-dose steroid therapy.

\section{CASE REPORT}

An 11-year-old girl presented with pallor and petechiae on the trunk. CBC revealed a hemoglobin concentration $(\mathrm{Hb}) 7.6 \mathrm{~g} / \mathrm{dL}$, white blood cell count (WBC) 4,690/ $\mu \mathrm{L}$, platelet count $13,000 /$ $\mu \mathrm{L}$ : and bone marrow aspiration and biopsy findings were consistent with myelodysplastic syndrome (refractory anemia). The cytogenetic study revealed normal female chromosome. She received only intermittent transfusions of packed red cells or platelets, until when underwent unrelated

\footnotetext{
Correspondence to : Young-Ho Lee, M.D.

Department of Pediatrics, Hanyang University Medical Center 17, Haengdang-dong, Seongdong-gu, Seoul 133-792, Korea

Tel: +82-2-2290-8383, Fax: +82-2-2297-2380

E-mail: cord@hanyang.ac.kr
} 


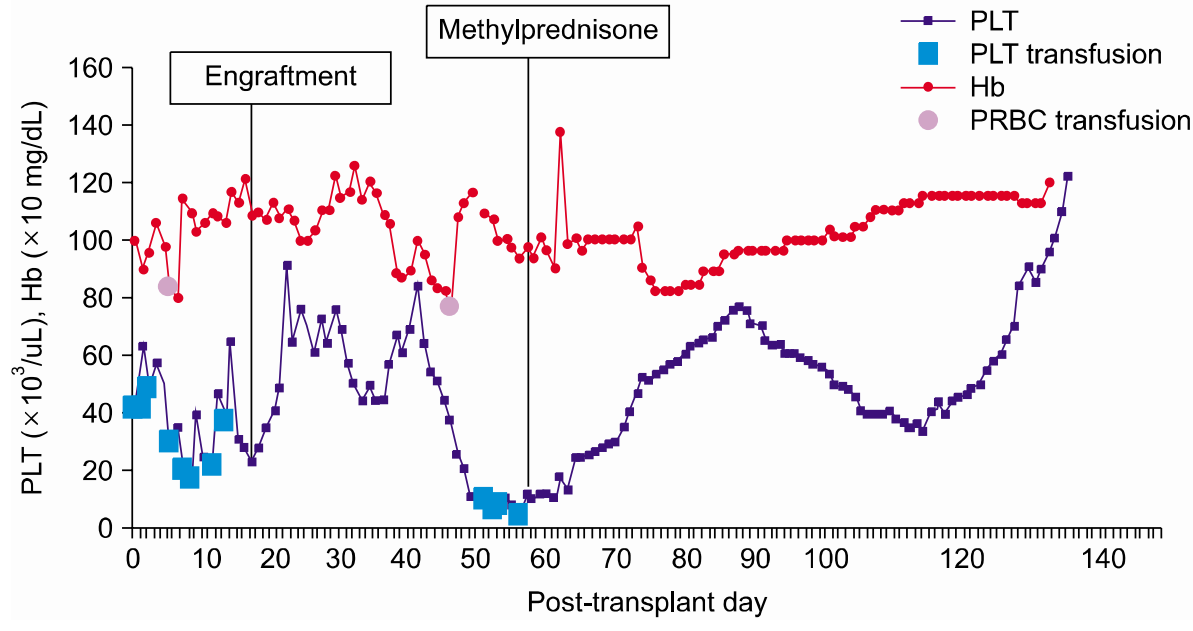

Fig. 1. Laboratory parameters before and after onset of Evans syndrome following unrelated bone marrow transplantation. Abbreviations: PLT, platelet; $\mathrm{Hb}$, hemoglobin.
BMT from Japan Marrow Donor Program. The donor was same with this child in DNA basedHLA type, blood type $(\mathrm{Rh}+, \mathrm{B})$ and sex.

Pretransplant conditioning was done with busulfan $(0.8 \mathrm{mg} / \mathrm{kg}$, i.v. every 6 hours for 4 days, total dose $12.8 \mathrm{mg} / \mathrm{kg})$ and cyclophosphamide $(60$ $\mathrm{mg} / \mathrm{kg} /$ day, i.v. for 2 days, total dose $120 \mathrm{mg} / \mathrm{kg}$ ). GVHD prophylaxis consisted of tacrolimus (0.05 $\mathrm{mg} / \mathrm{kg} /$ day $)$ and methotrexate $\left(10 \mathrm{mg} / \mathrm{m}^{2}\right.$, i.v. $)$ Prophylaxis against venoocclusive disease used lipo$\mathrm{PGE}_{1}$ (lipoprostaglandin $\mathrm{E}_{1}, 1 \mu \mathrm{g} / \mathrm{kg} /$ day, i.v.). Granulocyte colony-stimulating factor $(5 \mu \mathrm{g} / \mathrm{kg} / \mathrm{day}$, i.v.) was used from day +5 after transplant until the absolute neutrophil count exceeded $1,000 / \mu \mathrm{L}$.

She was engrafted promptly on day +10 for neutrophil and on day +18 for platelet. She experienced mild hemorrhagic cystitis and grade I skin GVHD, which easily controlled with supportive therapy. Chimerism study with PCR (polymerase chain reaction) of STR (short tandem repeat) on day +21 showed $100 \%$ donor hematopoiesis. Bone marrow biopsy was done on day +35 , which revealed trilineage engraftment with $40 \%$ of cellularity.

Until 42 days after transplant, platelet count was steadily increased to $90,000 / \mu \mathrm{L}$ and $\mathrm{Hb}$ level was maintained above $10 \mathrm{~g} / \mathrm{dL}$. Since then, her hemoglobin level was decreased to $7.6 \mathrm{~g} / \mathrm{dL}$ and platelet count below 20,000/ $\mu$ L. For evaluating post-engraftment cytopenia, we repeated bone marrow study and chimerism study which revealed persistent trilineage engraftment with $100 \%$ donor hematopoiesis. Tests for bacterial and viral infections (cytomegalovirus, EpsteinBarr virus, herpes virus) were negative. We also performed the tests for hemolysis, which showed increased level of indirect bilirubin $(2.5 \mathrm{mg} / \mathrm{dL})$, serum LDH (532 U/L), and corrected reticulocyte count (1.6\%). The direct Coombs test and platelet associated antibody were positive, but indirect Coombs test and antiplatelet antibody were negative.

High-dose methylprednisone $(30 \mathrm{mg} / \mathrm{kg} / \mathrm{day})$ was administered intravenously for 3 days from day +61 with maintaining therapeutic tacrolimus level. Within 1 week, her platelet count and hemoglobin concentrates stabilized without transfusion and steadily increased. Although the hemoglobin level normalized by day +66 , the platelet counts transiently decreased again by day +98 due to herpes zoster infection and increased to normal level by day +126 . The direct Coombs test was converted to negative on day +115 (Fig. 1). She continues the evidence of trilineage hematopoiesis with obviously well conditions.

\section{DISCUSSION}

Autoimmune cytopenia, particularly autoimmune hemolytic anemia (AIHA) is uncommon 
complication after hematopoietic stem cell transplantation of allogeneic or autologous source. Although the incidence of AIHA after allogeneic BMT was estimated at $3 \%,^{1,13)}$ the increased incidence $(15.5 \%)$ of AIHA after T cell depleted stem cell transplantation was noted. ${ }^{4)}$

Evans syndrome also has been rarely described in recipients who underwent allogeneic BMT, ${ }^{12,13)}$ unrelated cord blood stem cell transplantation, ${ }^{11)}$ or autologous BMT. ${ }^{14)}$ They also received potent $\mathrm{T}$ cell suppression with antithymocyte globulin (ATG) and/or OKT3 as part of the conditioning regimen. Dovat et $\mathrm{al}^{11)}$ reported the 8 -month-old male with Evans syndrome which developed on 4 months after cord blood stem cell transplantation. $\mathrm{He}$ received multiple courses of intravenous immunoglobulin, anti-Rh D immunoglobulin, a pulse of high-dose corticosteroids and cyclosporine with only some improvement of hemolytic anemia, but no improvement of the thrombocytopenia. Addition of vincristine resulted in longterm resolution of thrombocytopenia and anemia. Drobyski et al $^{1)}$ also reported the 27-year-old female who experienced Evans syndrome after unrelated bone marrow transplantation and showed partial response to various kinds of treatment such as steroids, immunoglobulin, ATG, danazole/vincristine, and plasma pheresis.

Although there are controversies regarding the concomitance with the onset of hemolysis and leukemic relapse, in many instances, the onset of hemolysis coincided with the cessation of immunosuppressive therapy., ${ }^{3,15}$ These evidences probably reflect increased defective regulation of autoreactive $\mathrm{B}$ cells as a consequence of $\mathrm{T}$ cell defects and consequently an increase in autoimmune disorders. ${ }^{1)}$ Although our patient received $\mathrm{T}$ cell repleted bone marrow from unrelated donor following conditioning regimen with busulfan and cyclophosphamide without ATG or OKT3, she developed thrombocytopenia and Coombs' positive hemolytic anemia 42 days after unrelated BMT. She was on immunosuppressive treatment with complete chimerism of donor type, and responded very well to high-dose methylprednisone. She experienced several times of viral infections following this event of Evans syndrome, which suggests still noted impairment of $\mathrm{T}$ cell function although we could not perform the immunologic studies.

Although immune hemolysis due to $\mathrm{ABO} / \mathrm{Rh}$ mismatch occurs within first 6 weeks following BMT, the cases of autoimmune hemolytic anemia arise longer than 8 weeks post-BMT. Chen et $\mathrm{al}^{13)}$ reported autoimmune hemolytic anemia following BMT as two distinct groups: an early onset group associated with cold antibody occuring between 2 and 8 months and a late onset group associated with warm antibody occurring between 6 and 18 months after BMT. Our patient who received $\mathrm{ABO} / \mathrm{Rh}$ matched marrow developed hemolysis on day +42 after BMT, which may reflect autoreactive donor $\mathrm{B}$ cells might begin Ig $\mathrm{M}$ production and destroy red cells. The response to treatment was also rapid and complete because, even we are not sure, the cold antibody in the early onset group may be clinically benign.

In our case, although we could not find the previously reported etiologies such as concurrent viral infections, the use of T-cell depleted marrow or ATG/OKT3 as a part of conditioning regimen, and the reduction of immunosuppressive drugs, we experienced the early onset type of Evans syndrome promptly responded to high-dose corticosteroid.

\section{요 약}

조혈모세포이식 이후에 발생하는 Evans 증후군 은 아주 드물게 발생하며, 치료에 반응을 잘하지 않 는다. 저자들은 $\mathrm{T}$ 세포를 제거하지 않은 비혈연 골 수이식 이후에 발생한 Evans 증후군을 경험하였는 데, 이식 후 42일째 발생하였으며 고용량의 스테로 이드 치료에 잘 반응하였다. 따라서 조혈모세포이 식 후 생착이 된 다음에 발생하는 혈구감소증의 경 우에는 자가면역성 혈구감소증도 의심하여야 하겠 다. 


\section{REFERENCES}

1) Drobyski WR, Potluri K, Sauer D, Gottschall JL. Autoimmune hemolytic anemia following $\mathrm{T}$ cell-depleted allogeneic bone marrow transplantation. Bone Marrow Transplant 1996;17:1093-9.

2) Pratt G, Kinsey SE. Remission of severe, intractable autoimmune haemolytic anaemia following matched unrelated donor transplantation. Bone Marrow Transplant 2001;28:791-3.

3) De Lord C, Marsh JC, Smith JG, Singer CR, GordonSmith EC. Fatal autoimmune pancytopenia following bone marrow transplantation for aplastic anaemia. Bone Marrow Transplant 1996;18:237-9.

4) Cwynarski K, Goulding R, Pocok C, et al. Immune haemolytic anaemia following $\mathrm{T}$ cell-depleted allogeneic bone marrow transplantation for chronic myeloid leukaemia: association with leukaemic relapse and treatment with donor lymphocyte infusions. Bone Marrow Transplant 2001;28:581-6.

5) Jillella AP, Kallab AM, Kutlar A. Autoimmune thrombocytopenia following autologous hematopoietic cell transplantation: review of literature and treatment options. Bone Marrow Transplant 2000;26:925-7.

6) Wahid FS, Cheong SK, Sivagengei K. Autoimmune thrombocytopenia and neutropenia after autologous peripheral blood stem cell transplantation. Acta Haematol 2002;107:237-38.

7) Evans RS, Takahashi K, Duane RT, Payne R, Liu C.
Primary thrombocytopenic purpura and acquired hemolytic anemia; evidence for a common etiology. AMA Arch Intern Med 1951;87:48-65.

8) Pui CH, Wilimas J, Wang W. Evans syndrome in childhood. J Pediatr 1980;97:754-8.

9) Wang WC. Evans syndrome in childhood: Pathophysiology, clinical course and treatment. Am J Pediatr Hematol Oncol 1988; 10:330-8.

10) Wang W, Herrod H, Pui CH, Presbury G, Wilimas J. Immunoregulatory abnormalities in Evans syndrome. Am J Hematol 1983;15:381-90.

11) Dovat $S$, Roberts RL, Wakim M, Stiehm ER, Feig SA. Immune thrombocytopenia after umbilical cord progenitor cell transplant: response to vincristine. Bone Marrow Transplant 1999;24:321-3

12) Winiarski J, Ringdén $O$, Remberger $M$, Dalianis $T$, Ljungman P, Borgström B. Bone marrow transplantation in children using unrelated donors. Acta Paediatr 1996;85:327-35.

13) Chen FE, Owen I, Savage D, et al. Late onset hemolysis and red cell autoimmunisation after allogeneic bone marrow transplant. Bone Marrow Transplant 1997;19: 491-5.

14) Keung YK, Cobos E, Bolanos-Meade J, Issarachai S, Brideau A, Morgan D. Evans syndrome after autologous bone marrow for recurrent Hodgkin's disease. Bone Marrow Transplant 1997;20:1099-101.

15) Bashey A, Owen I, Lucas GF, et al. Late onset immune pancytopenia following bone marrow transplantation. Br J Haematol 1991;78:268-74. 